\title{
Yöneticilerin İ̧̧ Sağlığı ve Güvenliği Uygulamalarına Yönelik Algılarının Analizi Üzerine Bir Araştırma
}

\author{
A Study about the Perceptions of Managers on \\ Occupational Health and Safety Practices
}

Fatma Zehra TAN, Suat ÇALIŞKAN

\begin{abstract}
ÖZET
Günümüzde yaşanan iş kazası ve meslek hastalıkları büyük ekonomik ve sosyal sorunlara yol açan bir olgu haline gelmiştir. Bu süreçte hem devletler hem de işletmeler, iş kazası ve meslek hastalıklarını önlemeye yönelik bir takım yasal ve politik adımlar atmaya başlamışlardır. Nitekim ülkemizde 2012 yılında 6331 sayılı İs Sağlığı ve Güvenliği Kanunu yürürlüğe girmiştir. Bu çerçevede çalıșmada, işletmelerde 6331 sayılı İş Sağlığı ve Güvenliği Kanununun gereklerinin yerine getirilip getirilmediğine ilişkin alt kademedeki yönetici/çalışanların algıları ölçülmek istenmiştir. Araştırmada, 6331 sayılı iş sağlığı ve güvenliği kanunu kapsamındaki iş sağlığı ve güvenliği uygulamalarına yönelik algının olumlu olduğu ve katılımcıların demografik özelliklerine göre anlamlı bir farklılık göstermediği saptanmıștır.
\end{abstract}

Anahtar Kelimeler: İş Sağlığı, İş Güvenliği, İş Sağlığı ve Güvenliği, 6331 sayılı İş Sağlığı ve Güvenliği Kanunu

\section{ABSTRACT}

The occupational accidents and diseases which are experienced nowadays have become an issue causing major economical and social problems. In this process, both states and companies have taken a number of legal and political cautions to prevent these occupational accidents and diseases. Thus, no. 6331 Occupational Health and Safety Legislation came into force for our country in 2012. In this context, this study intended to measure the perception of employees regarding whether the relevant laws are fulfilled in the companies or not. In this research, it has been determined that the perception of occupational health and safety practices in the scope of the relevant law is positive and participants have no significant difference according to their demographic characteristics.

Keywords: Occupational Health, Occupational Safety, Occupational Health and Safety, No. 6331 Occupational Health and Safety Legislation

Doç. Dr. Fatma Zehra TAN - Karabük Üniversitesi, İşletme Fakültesi, Karabük, Türkiye Assoc. Prof. Fatma Zehra TAN-Karabuk University, Faculty of Business, Karabuk, Turkey fatmazehra@karabuk.edu.tr

Dr. Suat ÇALIŞKAN - Karabük Üniversitesi, Sosyal Bilimler Enstitüsü, Karabük, Türkiye Suat CALISKAN, PhD - Karabuk University, Institute of Social Sciences, Karabuk, Turkey suatcaliskan50@gmail.com 


\section{GİRIŞ}

6331 sayılı İş Sağlığı ve Güvenliği Kanunu (R.G: T. 30.06.2012, S. 28339), 30/06/2012 tarihinde Resmi Gazete'de yayınlanmış ve 01.01.2013 tarihinden itibaren de bir çok maddesi yürürlüğe girmiştir [1,2]. 6331 sayılı İSGK yürürlüğe girmeden önce İSG uygulamalarına ilişkin hususlar 4857 sayılı Türk İş Kanunu'nda (RG: T. 10.6.2003, S. 25134) yer almaktaydı [3]. 6331 sayılı İş Sağlığı ve Güvenliği Kanunu, AB'nin 89/391 sayılı çerçeve direktifi ve ülkemizce kabul edilmiş bulunan 155 ve 161 sayılı ILO (Uluslararası Çalışma Örgütü) sözleşmeleri gözetilerek kaleme alınmıstır [4]. 6331 sayılı yasa ve bu yasaya dayanılarak oluşturulan İSG mevzuatının 2013 yılı itibariyle yürürlüğe girmesi ile çalışma hayatında yeni bir dönem başlamıştır.

Türkiye, meydana gelen iş kazaları ve meslek hastalıklar1 alanında dünyada üçüncü, Avrupa'da ise birinci sırada yer almaktadır [5,6,7]. Bunun kabul edilebilir bir durum olmadığı ortadadır. Günümüzde, iş kazaları ve meslek hastalıkları çözümlenmesi gereken bir sosyal olgu olarak karşımızda durmaktadır. İş kazaları ve meslek hastalıklarının önlenmesi anlamında İSG uygulamaları işverenler ve işveren vekilleri sıfatıyla işletme yöneticileri açısından önemli hale gelmiştir.

İş kazaları ve meslek hastalıkları, İSG konusuna yeterli önemin verilmemesi, yasalardaki sorunlar, denetim eksikliği, sermayenin işçi sağlığı ve iş güvenliği alanını maliyet olarak görmesi, eğitim eksikliği, güvenlik kültüründeki hatalı uygulamalar ve benzeri sebeplerden kaynaklanmaktadır. Çalışma alanının çalışanlar için sağlık ve güvenlik açısından uygun hale gelmesi, işyerlerinde sağlık ve güvenlik kültürünün oluşturulması ile mümkündür $[8,6]$. İSG uygulamalarında, işletme yöneticilerine İSG mevzuatından kaynaklanan bir takım görevler düştüğünü ve bu uygulamalar nedeniyle sorumluluklarının bulunduğunu ifade etmeliyiz. Bu nedenle, işletmelerde çalışan yöneticilerin İSG uygulamalarına yönelik algılarının, o işletmelerdeki İSG uygulamalarının düzeyini, seyrini ve denetimini etkileyebileceği düşünülmektedir.

$\mathrm{Bu}$ çalışmada, çok riskli bir işkolunda faaliyet gösteren kurumsal bir işletmede çalı̧̧an alt kademe yöneticilerinin, iş sağlığı ve güvenliği uygulamalarına yönelik algı düzeylerinin belirlenmesine çalışılacaktır. Çalışanların iş sağlı̆̆ı ve güvenliği algı düzeyleri çeşitli demografik değişkenler bakımından farklılık gösterip göstermediği İSG uygulamalarının işletme içindeki düzeyi, seyri ve takibi açısından önemlidir. Buna göre; çalışanların cinsiyetlerine, yaş gruplarına, eğitim düzeylerine, hizmet sürelerine göre anlamlı bir farklılık gösterip göstermediği tespit edilmeye çalışılacaktır.

\section{KURAMSAL ÇERÇEVE}

İş Sağlığı ve Güvenliği (İSG) uygulamalarında, iş sağlığ1 ve güvenliği, iş kazaları ve meslek hastalığı kavramları ön plana çıkmaktadır. Bu uygulamalar esas olarak, iş kazaları ve meslek hastalıklarının önlenmesi için vardır.

\section{A. İş Sağlığı}

Sağlık, her şeyden önce bir insan hakkı olarak kabul edilmekte ve tıbbi, sosyolojik ve psikolojik açıdan ele alınmaktadır [9]. Dünya Sağlık Örgütü’ne göre sağlık kavramı; sadece hastalık ve sakatlıkların yokluğu açısından değerlendirilmemektedir; bu husus dışında sağlık kavramı bedensel, ruhsal ve sosyal yönden tam bir iyilik hali içerisinde olma durumunu da içermektedir $[10,9,11,13,14,4,15,16]$. İş sağlığı kavramı da öncelikle sağlık kavramını içermektedir [10]. Başka bir deyişle iş sağlı̆̆ kavramı, hem iş hem de işçi sağlığını kapsayan bir kavramdır [17]. İş sağlığı, iş yerinde bir hastalığın veya fiziki ortamda bulunanlarda bir 
zararın bulunmasının ötesinde işyerindeki güvenlik ve hijyenle doğrudan ilgili olup, sağlığı etkileyen maddi ve manevi unsurları içerir $[18,19]$. Bu bağlamda, iş sağlığı, çalışanların çalışma koşulları, çalışma ortamı ile kullanılan araç ve gereçlerden meydana gelebilecek tehlikeli durumların ortadan kaldırıldığı ya da en aza indirildiği sağlıklı bir iş ortamında çalışmasıdır [20]. İş sağlığı, çalışma alanında bulunan ve çalışanların sağlığı açısından risk oluşturabilecek unsurlardan çalışanın sağlığının korunması anlamındadır [21,22]. Literatürde iş sağlığı ile ilgili yapılan tanımlarda, bu risk kavramının gözetildiği görülmektedir $[22,23,16]$.

\section{B. İş Güvenliği}

İş güvenliği kavramı; çalışanların iş kazalarına ve meslek hastalıklarına karşı korunmalarını sağlamak için İSG mevzuatında yer alan önlemlerin alınması ve güvenli çalışma ortamını oluşturmak adına hukuki, teknik ve tıbbi anlamda yapılan işlemler bütünü şeklinde tanımlanmaktadır $[13,24,25,26,14,6,22]$. İş güvenliği, çalışma ortamında doğabilecek tehlikelerin ve sağlığa zarar verebilecek unsurların ortadan kaldırılması olarak ifade edilmektedir [27]. Başka bir deyişle, çalışma alanında kullanılan makine, donanım, iş aletlerine bağı ılarak ortaya çıkabilecek risklerin belirlenmesi ve bunlara karşı önlem alınmasıdır. Bu şekilde çalışma ortamının tehlikelerden arındırılması ile daha iyi bir çalışma ortamı sağlanabileceği savunulmaktadır [28].

\section{C. İş Sağlığı ve Güvenliği}

4857 sayılı İş Kanunu ile birlikte, "iş̧̧i sağlığı ve iş güvenliği" olarak İSG literatürüne yerleşmiş olan kavram "İş Sağlığı ve Güvenliği" olarak değiş̧tirilmiş̧tir. "İşçi Sağlığı" kavramı, çalışma alanında meydana gelebilecek iş kazasının (örneğin büyük çaplı bir patlamanın) işyeri çevresinde yaşayanlara da zarar verebileceği düşüncesinden hareketle "İş Sağlığı” olarak değiştirilmiştir [13]. İSG, çalışma ortamın- da çalışanların sağlığını ve iş güvenliğini sağlamak, çalışma ortamında doğabilecek, iş kazası ve meslek hastalıkları gibi her türlü riske karşı gerekli tedbirleri almak, çalışma ortamında çalışma için gerekli araç-gereçleri noksansız bulundurmak İSG açısından çok önemlidir. İSG uygulamaları, işverenin ve yöneticilerin sorumlu tutulduğu ve çalışanların İSG uygulamalarında öngörülen önlemlere uymalarını isteyen bir kavram olarak karşımıza çıkmaktadır.

Literatürde iş sağlığı ve güvenliği kavramına ait birçok tanım bulunmaktadır $[29,30,22,21,28,31,32]$. İş sağlığı ve güvenliği kavramı, dar ve geniş anlamda olmak üzere farklı tanımlara tabi tutulmaktadır. Dar anlamı ile iş sağlığı ve güvenliği, çalışanın sağlık ve güvenliğinin çalışma ortamında ve çalışma nedeniyle oluşabilecek tehlikelere karşı korunması olarak tanımlanmaktadır [33]. Geniş anlamda iş sağlığı ve güvenliği ise, sadece çalışma yerinde değil çalışma yeri dışında da olsa çalışanın ve yaşam alanında bulunan öznelerin sağlık ve güvenliğini olumsuz etkileyebilecek risklere karşı önlem alınmasını ve tehlikelerden korunması olarak tanımlanmaktadır [13].

İSG, bir işletmenin gerçekleştirdiği çalışma işlemlerinden zarar gören tüm İSG öznelerinin (çalışanların, geçici işçilerin, alt yüklenici çalışanlarının, ziyaretçilerin, müşterilerin ve işyerindeki herhangi bir kişinin) sağlığına ve güvenliğine zarar verebilecek unsurlar üzerinde durmaktadır $[32,14,34]$. Dolayısıyla iş sağlığı ve güvenliği, işin çalışana ve çalışanın işe uydurulması amacından hareket ederek, her tür sektörde çalışanın, çalışma ortamı ve koşullarından dolayı sağlık durumlarında meydana gelecek bozulmayı önlenmek, çalışanların fiziksel ve ruhsal yapılarına göre uygun işlere yerleştirilmeleri büyük önem taşımaktadır [35].

\section{D. İş Kazası}

Kaza kavramı; belirli bir nedene bağlı olmayan, önce- 
den bilinmeyen, beklenmeyen, amaca bağlı olmayan ve tesadüfi bir şekilde gerçekleşen istenmeyen ve olumsuz sonuçlar doğuran olguların meydana gelmesi şeklinde tanımlanabilir $[36,37,38,14,39,40]$. İş kazasının ise literatürde farklı bakış açıları ile tanımlandığı görülmektedir [38]. Fiziksel faktörler dikkate alındığında iş kazaları, işçinin çalışma süresince çalışma koşulları, işin nitelik ve yürütümü ya da kullanılan makine, araç, gereç ve malzeme nedeni ile uğradığı, işgücünün tamamını ya da bir bölümünü kaybettiği olay şeklinde tanımlanması mümkün gözükmektedir [41,42,37]. Bazı yazarlar ise iş kazasını, "sigortalının işveren otoritesi altında bulunduğu bir sırada gördüğü iş veya işin gereği dolayısıyla aniden ve dıştan meydana gelen bir etkenle onu bedenen veya ruhça zarara uğratan bir olay” olarak tanımlanmaktadır [43].

WHO iş kazasını, “önceden planlanmamış, çoğu zaman yaralanmalara, makine ve teçhizatın zarara uğramasına veya üretimin bir süre durmasına yol açan olay" olarak nitelendirmektedir [1,44,39]. ILO ise iş kazasını, "belirli bir zarar veya yaralanmaya yol açan, önceden planlanmamış beklenmedik bir olay" şeklinde tarif etmiştir [1,45,46,47,48]. 6331 sayılı İSG Kanununun 3/g maddesine göre iş kazası; işyerinde veya işin yapılması nedeniyle meydana gelen, ölüme sebebiyet veren veya vücut bütünlüğünü ruhen ya da bedenen engelli hâle getiren olay olarak tanımlamıştır $[32,38,14,6,46]$.

İş kazasının, sigortalının işveren egemenliği altında bulunduğu bir sırada yapılan çalışma veya çalışmanın gereği nedeniyle aniden ve dıştan meydana gelen bir etkenle çalışanı bedenen veya ruhça zarara uğratan bir olay olduğu söylenebilir. 5510 sayılı Sosyal Sigortalar ve Genel Sağlık Sigortası Kanunu (SSGSSK) m.13'de “ iş kazasının tanımı, bildirilmesi ve soruşturulması" başlığı altında iş kazasının tanımı verilmekten çok hangi şartlarda meydana gelen olayın iş kazası sayılacağı düzenlenmiştir $[49,38,46]$.

\section{E. Meslek Hastalığ}

Meslek hastalıkları çalışan kişinin, işi sebebiyle maruz kaldığı şartlar dolayısıyla, sağlık durumunda meydana gelen bozukluklar ve aksamalar olarak tarif edilebilir $[47,7]$. Dünya Sağlık Örgütü (WHO) ve Uluslararası Çalışma Örgütü (ILO) gibi uluslararası kuruluşlara göre, meslek hastalıkları, zararlı bir etkenle insanın zarar gördüğü, bu zararla yapılan iş arasında neden-sonuç ilişkisinin (illiyet bağı) kurulabildiği hastalıklardır [50]. Meslek hastalığı, belirli bir mesleğin (işin) ifası sonucu o mesleğin (işin) nitelik ve yürütüm şartların doğurduğu bir sakatlık veya hastalıktır [43,7]. 6331 sayılı İş Sağlığı ve Güvenliği Kanunu'nda, m. 3/l'de meslek hastalığ1; "Mesleki risklere maruziyet sonucu ortaya çıkan hastalık" olarak tanımlanmıştır $[32,6,51]$.

Meslek hastalıkları, genel olarak mal ve hizmet üretiminden kaynaklanır ve bu nedenle diğer hastalıklardan ayrı bir değerlendirmeye tabi tutulur [6]. İş kazası ile meslek hastalığı arasındaki temel fark, ilkinde ani bir gelişmeye yol açan bir olay bulunmasına karşılık, ikincisinde sağlığın tedrici bir gelişme sonucunda bozulması durumu vardır. $\mathrm{Bu}$ çerçevede, 5510 sayılı SSGSSK m.14/I’e göre meslek hastalığı; "sigortalının çalıştığı veya yaptığı işin niteliğinden dolayı tekrarlanan bir sebeple veya işin yürütüm şartları yüzünden uğradığı geçici veya sürekli hastalık, bedensel veya ruhsal özürlülük halleridir” [25,50,7]. Buradaki tanımda belirtilen "tekrarlanan bir sebeple" ibaresi iş kazası ile meslek hastalığı arasındaki temel farkı ortaya koymaktadır. Çünkü iş kazası aniden, beklenmedik şekilde meydana gelirken meslek hastalığında tekrarlanan bir durum söz konusu olmaktadır [33]. Örneğin, çalışanın elini makinaya kaptırması "iş kazası" olarak kabul edilirken, kot kumlama işinde çalışanlarda ise tekrarlanan bir şekilde kumu solumaları sonucunda slikosiz hastalığının ortaya çıkması meslek hastalığı olarak nitelendirilmektedir. 
Türkiye'de meslek hastalığının tanımının bilimsellikten uzak ve yasal metinlerle sınırlı olduğu, meslek hastalıklarının “önlenebilir” özelliğinin göz ardı edildiği görülmektedir. Bunun yanı sıra kârını maksimize etmeye çalışırken işçiyi/emekçiyi “özürlü” yapan işveren/sermayedar adının "meslek hastalığı” tanımında geçmediği; yasaya göre sadece sigortalılar için "işin doğal niteliği” kaçınılmaz olarak "hastalık, bedensel veya ruhsal özürlülük” halini oluşturduğunun kabul edildiği yönünde ciddi eleştiriler yapılmaktadir [52].

\section{F. İSG Uygulamalarında Yöneticilerin Rolü}

İşletme yönetiminde İSG uygulamalarının yetersiz şekilde yönetilmesi iş kazalarının temel nedenleri (Man, Machine, Media) arasında gösterilmektedir. Yetersiz yönetim organizasyonu, tamamlanmamış kurallar ve talimatlar, yetersiz güvenlik yönetim planı, eğitim ve öğretim yetersizliği, uygun olmayan nezaret, yönetim ve rehberlik, uygun olmayan personel istihdamı, yetersiz sağlık kontrolleri vb. nedenler İSG yönetiminden kaynaklanabilecek eksikler arasında yer almaktadır [3]. İSG uygulamalarında yöneticilere büyük görevler düşmektedir. İş kazası ile meslek hastalıklarının önlenmesi İSG unsurlarının etkin ve etkili bir şekilde yönetilmesine bağlıdır. İSG uygulamalarında sorumluluk esas itibariyle, işletmede işverenin vekili sıfatıyla yöneticilere aittir. Sorumluluk aşağıdan yukarı doğru sirayet eder. Bireysel olarak alt kademe yöneticilerinden üst kademe yöneticilerine ve en nihayet işverene kadar sorumluluğun hareket edebileceği söylenebilir. Genel olarak İSG bir işletmede örgüt yapısı içinde bulunan herkesi ilgilendi$\operatorname{rir}[53]$.

Bir işletmede İSG uygulamalarında verimliliği artırmak için şu hususlar sağlanmalıdır; İlk olarak, iş güvenliğini destekleyen ve öncelik veren bir yönetim bağglılı̆̆ı oluşturulmalıdır [54]. İkinci olarak, İSG faaliyetlerine çalışan katılımı sağlanmalıdır. Üçüncü sırada da, güvenli davranışlar desteklenmelidir. İşletme yönetimi bu üç hususu dikkate alarak iş güvenliğini örgüt kültürünün bir parçası olarak görmelidir [8]. Yapılan çalışmalarda, güvenlik kültürü boyutları ile yöneticilerin güvenlik kültürüne yönelik tutum ve davranışları arasında anlamlı bir ilişki olduğu ve bu ilişkinin güvenlik kültürünün tüm boyutlarında pozitif yönde gelişme gösterdiği ortaya çıkmıştır [8]. Öğretide, işletme yönetiminin ve yöneticilerin tutum ve davranışlarının; güvenlik önceliği, güvenlik iletişimi ve güvenlik eğitimi gibi unsurları olumlu yönde etkilediği dile getirilmektedir [8]. İş sağlı̆̆ı ve güvenliğini sağlamak için, işletmelerin sadece kendi çalışanlarını değil toplumu da İSG konusunda bilinçlendirmeli ve topluma İSG kültürünü aşılamalıdır $[55,14]$.

Yöneticilerin İSG konusundaki rolleri şu şekilde ifade edilebilir [56]:

ISG Politikaları Geliştirme ve Uygulama: ş่letme yönetimi İSG politikaları geliştirmeli ve bu politikaları uygulamaya geçirmelidir: Bu anlamda, risk değerlendirmesi, güvenlik denetimleri ve teftişlerin yapılması için gerekli işlemlerin yürütülmesine ihtiyaç vardır. İşletme yönetimi, İSG performansını izlemeli, değerlendirmeli ve gerektiği durumlarda müdahale etmelidir.

ISG Uygulamalarını Sürekli İzleme ve Kontrol: Yöneticiler ISG konusuna ilgi göstermek zorundadır: İSG tüm unsurları ile yöneticilerin kontrolünde olmalı, güvensiz koşullar veya uygulamalar sürekli izlenmelidir. İş kazalarının büyük çoğunluğu çalışanların güvenli olmayan davranışları sonucunda gelmektedir [20]. Bu gibi durumlarda gerekli önlemleri almak yöneticilerin görevidir. Çalışanların İSG tehlikelerinin farkında olması ve risk almaması yöneticilerin sorumluluğundadır. 
Çalışanların Güven İçinde Çalışmasını Sağlama: Çalışanlar güvenli çalışma ilkeleri çerçevesinde çalışmalı ve çalışanlar ile işletme yöneticileri bu güvenli İSG uygulamalarının farkında olmalıdırlar. Yöneticilerin İSG uygulamalarına yönelik algıları farkındalık düzeylerini belirlemektedir. Algılama, dış dünyadaki soyut/somut nesnelere ilişkin olarak aldığımız duyumsal (sensible) ve bilgisel (information) verileri değerlendirme ve sonuç çıkarma sürecidir [57]. Algılama, simgesel, görsel, duygusal ve seçilmeye bağlı olarak gerçekleşebilir [57]. İSG uygulamalarına yönelik yönetici algıları da bu bağlamda gerçekleşmektedir. Algı düzeyinin yüksekliği, yöneticilerin İSG uygulamalarına yönelik farkındalıklarını yükseltmekte ve İSG ile ilgili duyarlılık seviyesini geliştirmektedir. Bu nedenle yöneticilerin, İSG uygulamalarına yönelik algıları ve bunun düzeyi önem arz etmektedir.

İletişim ve Eğitim İkânı Sağlama: ş ${ }^{\circ}$ letme yönetimi ve yöneticilerin iletişim ve eğitim görevlerini eksiksiz yerine getirme yükümlülükleri bulunmaktadır. $\mathrm{Bu}$ yükümlülük çalışma sırasında da kesintisiz devam etmelidir.

İSG Özneleri Arasında Işbirlĭ̆ini Sağlama ve Koordinasyon: şletme yöneticileri, saúlık ve güvenlik kurulları ile birlikte İSG konusunda etkin ve verimli bir çalışma gerçekleştirmelidirler. Bilindiği üzere, sağlık ve güvenlik kurulları İSG politikaları, İSG işlemleri ve güvenli çalışma usulleri konusunda çalışma yürütürler ve bu konudaki görüşlerini yönetime sunarlar. Bu kurullarda görev alan elemanlar, risk değerlendirmesi, güvenlik denetimleri, kaza incelemeleri gibi pek çok konu ile ilgilenirler. Ayrıca, İSG konusunda istatistikler oluştururlar ve meydana gelen İSG olaylarını rapor halinde sunarlar. Bunları yaparlarken yöneticilerle işbirliği yapmaları gerekmektedir. Bu noktada, yöneticilerin ortaya çıkan İSG uygulamalarını organize etme ve bu uygulamaları işletme bünyesine verimli bir şekilde yerleştirme görevleri bulunmaktadır. Sağlık ve güven- lik temsilcileri ise İSG konusunda faaliyet gösterirler ve ilgili kurularda üye olarak yer alırlar.

İşletme içinde yer alan tıbbi danışmanların, önleyici ve klinik olmak üzere iki görevi bulunmaktadır. Klinik görev, iş kazalarıyla, meslek hastalıkları ile ilgilenir. Bu anlamda, işten kaynaklanan ve meslek hastalığı olarak değerlendirilebilen hastalıklar ile ilgili iyileşme sürecine ilişkin gerekli olan adımlar ve yapılması gerekenler ile ilgili bilgi verir.

Güvenlik kurulları, İSG konusu ile ilgili temsilcilerden oluşur. İSG politikaları, işlemleri konusunda faaliyet gösterirler. Risk değerlendirmesi ve güvenlik denetimi konusunda işletme yönetimine yardımcı olurlar. İSG performansının geliştirilmesi için öneri sunarlar.

Çalışanların Sağlık ve Güvenliğini Koruma: Ülkemizde, İSG mevzuatı ve uygulamalarına göre, işveren ve işveren vekili sıfatıyla yöneticiler, işçinin sağlık ve güvenliğini korumakla yükümlüdürler. Bu konuda işletme dışındaki kuruluşlardan hizmet alınması bu yükümlülüğü kaldırmamaktadır [58,59]. Bu durumda, işyeri dışından hizmet alınan kişi ve kuruluşlarla işvereni İSG konusunda müteselsilen sorumlu tutmanın daha sağlıklı sonuçlar doğurabileceği hususu literatürde ifade edilmektedir [58].

İşletme yönetimi, işçi sağlığı ve güvenliğini korumak için, mesleki riskleri önlemeli, çalışanlara eğitim ve bilgi vermeli, İSG konusunda her türlü önlemi almalı, işin yürütümü ile İSG uygulamalarının organizasyonunu yapmalı, çalışanlara araç ve gereçleri temin etmelidir [60]. 6331 sayılı yasada öngörülen işveren yükümlülükleri, sorumluluk açısından işveren vekili sıfatıyla yöneticileri de ilgilendirmektedir. Bu yükümlülüklerin yerine getirilmesinde yöneticilerin de sorumluluğu bulunmaktadır. Sonuç olarak belirtmek gerekirse, işletmelerde İş Sağlığı ve Güvenliği Yönetim Sisteminin etkili bir şekilde uygulanması, o işletmelerde çalışanların moralini yükseltir, iş verimini arttırır, 
iş kazaları ve meslek hastalıklarını azaltır, işçi-işverenyönetici ilişkilerini olumlu yönde etkiler [20].

\section{ARAŞTIRMANIN METODOLOJİSI}

Çalışmanın bu kısmında evreni ve örneklemi açıklanacak olup ardından araştırma verilerinin toplanması ve analizi ile ilgili bilgiler verilecektir.

\section{A. Araştırmanın Evreni ve Örneklemi}

Araştırmanın evreni 2015-2016 yılında KARDEMİR A.Ş’de çalışan 165 alt düzeydeki yöneticilerdir. Dolayısıyla KARDEMİR A.Ş'de faaliyet gösteren alt düzeydeki yöneticilerin iş sağlığı ve güvenliği uygulamalarına ilişkin algıları demografik özelliklerine göre farklılık göstermekte midir? sorusuna cevap aranmaya çalışılmıştır. Örneklem büyüklüğünün hesaplanmasında ise evren büyüklüğünün bilinmesi durumunda kullanılması önerilen aşağıdaki formül kullanılmıştır [61];

$$
n=\frac{N \cdot t^{2} \cdot p \cdot q}{d^{2}(N-1)+t^{2} p q}
$$

Yukarıdaki formülde, evren hacminin 165, anlamlılık düzeyi 0,05 ve $Z$ tablosundaki değeri 1,96 , hata oranı $\pm 0,05$, incelenen olayın görülüş ve görülmeyiş sıklıkları 0,05 olarak yerine konulduğunda, örneklem hacminin yaklaşık 115,6 kişi olduğu hesaplanmış olup bu araştırmaya 117 kişi dâhil edilmiştir [62,63]. 117 kişiye uygulanan anketlerin tamamı değerlendirmeye alınmıştır.

\section{B. Araştırma Verilerinin Toplanması ve Analizi}

Yöneticilerin iş sağlığı ve güvenliği uygulamalarına ilişkin algılarını belirlenmek için anket yöntemi en uygun veri toplam araçlarından biridir. Bu yöntemde yüz yüze yapılan anketler daha sağlıklı sonuçlar verebilmektedir [64]. Araştırmada 34 ifadeden oluşan bir ölçek kullanılmıştır. Araş- tırmada kullanılan ölçek hazırlanırken iş sağlığı ve güvenliği ile ilgili literatür taranmış ve 6331 Sayılı İş Sağlığı ve Güvenliği Kanunu dikkate alınmıştır. Anket ölçeklerin hazırlanması ve geliştirilmesinde genel işlem basamakları olan; madde havuzu oluşturma, uzman görüşü, ön deneme, faktör analizi ve güvenirlik hesaplama çalışmaları takip edilmiştir [65]. Bu kapsamda uzman görüşleri kapsamında akademisyenlerin öneri ve eleştirileri doğrultusunda gerekli düzenlemeler yapılarak anket formu oluşturulmuş ve ön teste tabii tutulmuştur. Ön test, KARDEMİR AŞ'de faaliyette bulunan 100 alt düzey yönetici üzerinde gerçekleştirilmiştir. Araştırma verilerinin Kolmogorov-Simirnov testi sonucunda basıklık ve çarpıklık değerlerine ve Levene istatistiği sonuçlarına bakılarak parametrik testlere uygun olduğu tespit edilmiştir. Tüm test maddelerinin güvenirliği için Cronbach Alpha 0,972 hesaplanmıştır. Bu güvenirlik katsayısı, ölçeğin güvenirliğinin yüksek olduğunu ortaya koymuştur [66]. Ölçek Likert tipinde hazırlanmış olup katılımcılardan önermeleri (1) kesinlikle katılmıyorum, (2) katılmıyorum, (3) kararsızım, (4) katılıyorum ve (5) kesinlikle katılıyorum derecelerinde cevaplamaları istenmiştir. Ölçekte yer alan ifadelere yaş, cinsiyet, eğitim durumu ve KARDEMİR A.Ş’deki hizmet süresi değişkenleri için ttesti ve tek yönlü varyans analizi uygulanmıştır. Cinsiyet değişkeni açısından grup ortalamaları arasında anlamlı farklılıkların bulunup bulunmadığını belirlemek için ttesti; yaş, eğitim durumu ve hizmet süresi değişkenleri açısından ortalamalar arasında anlamlı farklılıkların bulunup bulunmadığını belirlemek için tek yönlü varyans analizi testi uygulanmıştır.

\section{ARAŞTIRMANIN BULGULARI}

$\mathrm{Bu}$ bölümde, araştırma sonuçlarına ilişkin elde edilen bulgulara yer verilmektedir. Araştırmaya katılan kişilerin 
tanımlayıcı bilgilerini tespit etmek amacıyla yapılan frekans ve yüzde dağılımları yer almaktadır. Tablo 1'de sunulmuştur.

Tablo 1: Tanımlayıcı Bilgilere Yönelik Bulgular

\begin{tabular}{|c|c|c|c|}
\hline \multicolumn{2}{|c|}{ Değişkenler } & \multirow{2}{*}{$\frac{\mathbf{F}}{21}$} & \multirow{2}{*}{$\frac{\%}{17,9}$} \\
\hline \multirow{5}{*}{ Yaş } & 30 Yaş ve Alt & & \\
\hline & 31-35 Yaş & 29 & 24,8 \\
\hline & $36-40$ Yaş & 24 & 20,5 \\
\hline & 41-45 Yaş & 25 & 21,4 \\
\hline & 46 Yaş ve Üstü & 18 & 15,4 \\
\hline \multirow{2}{*}{ Cinsiyet } & Kadın & 32 & 27,4 \\
\hline & Erkek & 85 & 72,6 \\
\hline \multirow{3}{*}{ Eğitim Durumu } & Lise ve Dengi & 41 & 35,0 \\
\hline & Üniversite & 45 & 38,5 \\
\hline & Lisansüstü & 31 & 26,5 \\
\hline \multirow{3}{*}{ Hizmet Süresi } & 3 Yıldan Az & 27 & 23,1 \\
\hline & 3-5 Yll & 32 & 27,4 \\
\hline & 5 Yıl Üzeri & 58 & 49,6 \\
\hline \multicolumn{2}{|c|}{ GENEL TOPLAM } & 117 & 100 \\
\hline
\end{tabular}

Tablo 1'de görüldüğü üzere; araştırmaya katılan kişilerden \%17,9'u 30 yaş ve altında, \%24,8'i 31-35 yaşında, \% 20,5’i 36-40 yaşında, \%21,4’ü 41-45 yaşında ve \%15,4’ü 45 yaşın üzerindedir. Katılımcılardan \%27,4’ü kadın, \% 72,6 's 1 ise erkektir. Katılımcılardan $\% 35$ 'i lise ve dengi, $\%$ 38,5'i üniversite ve \%26,5'i lisansüstü mezunudur. Kat1lımcıların \%23,1'i 3 yıldan az, \%27,4’ü 3-5 yıl, \%49,6's1 5 yıldan fazla bir süredir KARDEMİR A.Ş'de çalışmaktadır.

Katılımcıların iş sağlığı ve güvenliği uygularına yönelik ifadelere verdikleri cevaplar 3,40-4,00 puan aralığında ortaya çıkmış olup yöneticilerin algılarının genel olarak olumlu olduğu saptanmıştır.

Katılımcıların iş sağlığı ve güvenliği uygulamalarına ilişkin algılarından elde edilen ortalamaların yaşa göre an- lamlı farklılıklar gösterip göstermediğini belirlemek amacıyla tek yönlü varyans analizi uygulanmış ve elde edilen bulgular Tablo 2'de verilmiştir.

Tablo 2: Yaş Açısından İş Sağlığı ve Güvenliği Algısına Yönelik Tek Yönlü Varyans (One-Way ANOVA) Analizi Sonuçları

\begin{tabular}{|c|c|c|c|c|c|c|}
\hline & Değişkenler & $\mathrm{N}$ & $\bar{x}$ & s.s. & $\mathrm{F}$ & $P$ \\
\hline \multirow{5}{*}{ Yaş } & 1. 30 Yaş ve Alt & 21 & 3,948 & 0,437 & \multirow{5}{*}{0,398} & \multirow{5}{*}{0,810} \\
\hline & 2. $31-35$ YIl & 29 & 3,692 & 0,809 & & \\
\hline & 3. $36-40$ Yıl & 24 & 3,791 & 0,808 & & \\
\hline & 4. 41-45 Yıl & 25 & 3,767 & 0,877 & & \\
\hline & 5. 45 Yaş Üzeri & 18 & 3,833 & 0,453 & & \\
\hline \multicolumn{2}{|c|}{ TOPLAM } & 117 & 3,796 & 0,719 & & \\
\hline
\end{tabular}

$p<0.05^{*}$

Tablo 2'deki verilere bakıldığında; katılımcıların iş sağlığı ve güvenliğine ilişkin algılarının yaşa göre $\mathrm{p}<0.05$ anlamlılık düzeyinde bir farklılık bulunmaktadır $(\mathrm{F}=$ 0,398; $\mathrm{p}=0,810)$. Başka bir deyişle ölçeği cevaplayan bütün yaş gruplarında bulunan katılımcıların iş sağlığı ve güvenliği uygulamalarına yönelik algıları benzer şekildedir.

Katılımcıların iş sağlığı ve güvenliği uygulamalarına ilişkin algılarından elde edilen ortalamaların cinsiyete göre anlamlı farklılık gösterip göstermediğini belirlemek amacıyla t-testi uygulanmış ve elde edilen bulgular Tablo 3 'te verilmiştir.

Tablo 3: Cinsiyet Açısından İş Sağlığı ve Güvenliği Algısına Yönelik t-Testi (Indipendent Sample t Test) Sonuçları

\begin{tabular}{lcccccc}
\hline \multicolumn{2}{c}{ Değişkenler } & $\mathrm{N}$ & $\overline{\mathrm{X}}$ & s.s. & $\mathrm{T}$ & $\mathrm{P}$ \\
\hline \multirow{2}{*}{ Cinsiyet } & 1. Kadın & 32 & 3,983 & 0,612 & & \\
\cline { 2 - 5 } & 2. Erkek & 85 & 3,725 & 0,746 & & 0,084 \\
\hline TOPLAM & 117 & 3,854 & 0,679 & & \\
\hline
\end{tabular}

$\mathrm{p}<0.05^{*}$

Tablo 3'teki verilere bakıldığında kadın katılımcıların 
ortalaması $(\overline{\mathrm{X}}=3,983)$, erkek katılımcıların ortalamasına $(\overline{\mathrm{X}}=3,725)$ yakındır. Ortalamalar arasındaki bu yakınlık $\mathrm{p}$ $<0.05$ anlamlılık düzeyinde bir farklılığın olmadığını göstermektedir $(t=1,745 ; p=0,084)$. Başka bir deyişle ölçeği cevaplayan cinsiyet gruplarında bulunan katılımcıların iş sağı̆ğı ve güvenliği uygulamalarına yönelik algılarının benzer olduğunu söylemek mümkündür.

Katılımcıların iş sağlığı ve güvenliği uygulamalarına ilişkin algılarından elde edilen ortalamaların eğitim durumlarına göre anlamlı farklılıklar gösterip göstermediğini belirlemek amacıyla tek yönlü varyans analizi uygulanmış ve elde edilen bulgular Tablo 4’te verilmiştir.

Tablo 4: Eğitim Durumu Açısından İş Sağlı̆̆ı ve Güvenliği Algısına Yönelik Tek Yönlü Varyans (One-Way ANOVA) Analizi Sonuçları

\begin{tabular}{|c|c|c|c|c|c|c|}
\hline & Değişkenler & $\mathrm{N}$ & $\bar{X}$ & s.s. & $\mathrm{F}$ & $\mathrm{P}$ \\
\hline \multirow{4}{*}{$\begin{array}{l}\text { Eğitim } \\
\text { Durumu }\end{array}$} & 1. Lise ve Dengi & 41 & 3,616 & 0,804 & \multirow{3}{*}{2,018} & \multirow{3}{*}{0,138} \\
\hline & 2. Üniversite & 45 & 3,901 & 0,711 & & \\
\hline & 3. Lisansüstü & 31 & 3,881 & 0,570 & & \\
\hline & TOPLAM & 117 & 3,796 & 0,719 & & \\
\hline
\end{tabular}

Tablo 4'teki verilere bakıldığında; katılımcıların iş sağlığı ve güvenliğine ilişkin algıları eğitim durumlarına göre $\mathrm{p}$ $<0.05$ anlamlılık düzeyinde bir farklılık göstermemektedir $(\mathrm{F}=2,018 ; \mathrm{p}=0,138)$. Başka bir deyişle ölçeği cevaplayan bütün eğitim gruplarında bulunan katılımciların iş sağlığı ve güvenliği uygulamalarına ilişkin algılarının aynı olduğu söylenebilir.

Katılımcıların iş sağlığı ve güvenliği uygulamalarına ilişkin algılarından elde edilen ortalamaların hizmet süresine göre anlamlı farkl1lıklar gösterip göstermediğini belirlemek amacıyla tek yönlü varyans analizi uygulanmış ve elde edilen bulgular Tablo 5 'te sunulmuştur.

Tablo 5: Hizmet Süresi Açısından İşs Sağlığı ve Güvenliği Algısına Yönelik Tek Yönlü Varyans (One-Way ANOVA) Analizi Sonuçları

\begin{tabular}{|c|c|c|c|c|c|c|}
\hline & Değişkenler & $\mathrm{N}$ & $\bar{X}$ & s.s. & $\mathrm{F}$ & $P$ \\
\hline \multirow{4}{*}{$\begin{array}{l}\text { Hizmet } \\
\text { Süresi }\end{array}$} & 1. 3 Yıldan Az & 27 & 4,029 & 0,544 & \multirow{3}{*}{2,145} & \multirow{3}{*}{0,122} \\
\hline & 2. 3-5 YII & 32 & 3,801 & 0,697 & & \\
\hline & 3. 5 Yildan Fazla & 58 & 3,685 & 0,784 & & \\
\hline & TOPLAM & 117 & 3,796 & 0,719 & & \\
\hline
\end{tabular}

$\mathrm{p}<0.05^{*}$

Tablo 5'teki verilere bakıldığında; katılımcıların işs sağlığı ve güvenliğine ilişkin algıları hizmet sürelerine göre $\mathrm{p}<$ 0.05 anlamll1 lk düzeyinde bir farkl ll lk göstermemektedir (F $=2,145 ; \mathrm{p}=0,122)$. Dolayısıyla ölçeği cevaplayan bütün hizmet süresi gruplarında bulunan katılımcıların iş sağlığı ve güvenliği uygulamalarına ilişkin algılarının aynı olduğu söylenebilir.

\section{SONUÇ}

Dünyada yaşanan sanayileşme akımı ile birlikte sanayi sektörü hızla gelişmiştir. Bu olumlu gelişmeye karşıllık, iş güvenliği açısından da bir takım sorunlar ortaya çıkmıştır. Özellikle demir çelik sektörü gibi ağır iş kollarındaki işler ve işyeri ortamı doğrudan çalışanların, dolaylı olarak da toplumdaki diğer bireyleri etkileyen bir hal almaya başlamışlardır. Günümüzde, bu kadar büyük ekonomik ve sosyal sorunlara yol açan iş kazası ve meslek hastalıklarını önleme yolunda çaba sarf etmek, hem devlet hem de işletmeler için ortak bir vizyon halini almıştır [67]. Bu vizyon düşüncesinden hareketle Türkiye'de 6331 sayılı iş sağlığı ve güvenliği kanunu kapsamındaki iş sağlığı ve güvenliği uygulamalarına yönelik algıya ilişkin KARDEMİR A.Ş’de 


\section{2}

çalışan alt kademedeki yöneticiler üzerine alan araştırması yapılmıştır.

Alt düzey yöneticilerin iş sağlığı ve güvenliği uygulamalarına ilişkin ifadelere verdikleri cevaplara göre; iş sağlığı ve güvenliği kapsamında işletmelerde mesleki risklerin önlenmesi konusunda yetersizliklerin olmadığı, iş sağlı̆ğ ve güvenliği için gerekli araç ve gereçlerin sağlandığı, sağlık ve güvenlik tedbirlerinin değişen şartlara göre uyarlandığı ve mevcut sağlık ve güvenlik tedbirleri konusunda iyileştirmelerin yapıldığı saptanmıştır. Araştırmada, işletmelerde iş sağlığı ve güvenliğiyle ilgili yeterli eğitim ve bilgi verildiği, işletmelerde alınan iş sağlı̆̆ı ve güvenliği tedbirlerine uyulup uyulmadığı konusunda yapılan denetimlerin yeterli olduğu, çalışma ortamına ve çalışanların bu ortamda maruz kaldığı risklerin belirlenmesine yönelik gerekli kontrol, ölçüm, inceleme ve araştırmaların yapıldığı yönünde görüş bildirmişlerdir.

Çalışmada, işverenlerin işletmelerde işyeri hekimi veya sağlık personeli bulundurduğu ve işletmede görevlendirilen iş güvenliği uzmanlarının görevlerini yerine getirmeleri amaciyla araç, gereç, mekân ve zaman gibi gerekli bütün ihtiyaçları karşılandığına yönelik olumlu bir algının olduğu gözlenmiştir. Sonuçlara göre; işletmelerde görevlendirilen işyeri hekimi veya sağlık personelinin görevlerini yerine getirmeleri amaciyla araç, gereç, mekân ve zaman gibi gerekli bütün ihtiyaçları karşılanmakta olup sağlık ve güvenlik hizmetlerini yürütenler arasında iş birliği ve koordinasyon eksikliği yaşanmadığı yönünde katılımcılarda olumlu bir algının varlığı tespit edilmiştir. Ayrıca katılımcılar, işletmelerde görevlendirilen iş güvenliği uzmanları, işyeri hekimi veya sağlık personeli tarafından iş sağlığı ve güvenliği ile ilgili mevzuata uygun olan ve yazılı olarak bildirilen tedbirlerin yerine getirildiği yönünde görüş bildirmişlerdir.

Katılımcılara göre; işletmelerde iş güvenliği uzmanları- nın, işyeri hekimi veya sağlık personelinin görevlerini yerine getirmeleri konusunda hak ve yetkileri kısıtlanmamaktadır. İşletmelerde iş sağlığı ve güvenliği yönünden risk değerlendirmesi yapılmakta veya yaptırma yükümlülüğü yerine getirilmektedir. İşverenler işletmelerinde iş güvenliği uzmanı bulundurmaktadırlar. İşletmelerde önlenemeyen tehlikelerin meydana gelmesi durumunda, çalışanların işi bırakarak derhal çalışma yerlerinden ayrılıp güvenli bir yere gidebilmeleri sağlanmaktadır. İşletmelerde önlenemeyen tehlikelerin meydana gelmesi durumunda tehlikelere müdahalede bulunan çalışanlar yaptıkları müdahaleden dolayı sorumlu tutulmamaktadır.

Çalışmada; katılımcılar, işletmelerde bütün iş kazaları ve meslek hastalıklarının kaydının tutulduğu ve gerekli incelemelerin yapılarak raporlar düzenlendiği, işletmelerin iş kazalarını ve meslek hastalıklarını yasada belirtilen sürede Sosyal Güvenlik Kurumuna bildirimde bulundurdukları, çalışanların işyerinde maruz kalacakları sağlık ve güvenlik riskleri dikkate alınarak sağlık gözetimine tabi tutulmalarını sağladıkları yönünde görüş bildirmişlerdir. Bunun yanı sıra işletmelerde tehlikeli ve çok tehlikeli sınıfta yer alan işlerde çalışacakların, yapacakları işe uygun olduklarını belirten sağlık raporu olmadan işe başlatılmadığına, iş sağlığı ve güvenliğinin sağlanması ve sürdürülebilmesi konusunda, çalışanların ve çalışan temsilcilerinin işyerinin özelliklerini de dikkate alarak bilgilendirildiğine yönelik katılımcılarda olumlu bir kanının var olduğu söylenebilir. Ayrıca, işletmelerin, çalışanların iş sağlığı ve güvenliği eğitimlerini almalarını sağladığı, işyerinin değişik bölümlerindeki riskler ve çalışan sayılarına göre çalışan temsilcileri görevlendirildiği yönünde katılımcılarda olumlu bir algı bulunmaktadır.

Katılımcılar yine; işletmelerde, çalışan temsilcilerinin tehlike kaynağının yok edilmesi veya tehlikeden kaynaklanan riskin azaltılması için, işverene öneride bulunma hak- 
kının ihlal edilmediği, işletmelerde çalışan temsilcileri ve destek elemanlarının hakları kısıtlanmadığı ve görevlerini yerine getirebilmeleri için gerekli imkânların sağlandığı, işletmelerin, bina ve eklentilerinde, çalışma yöntem ve şekillerinde veya iş ekipmanlarında çalışanlar için hayati tehlike oluşturan hususlar tespit edildiği halde işletmenin bir bölümünde veya tamamında verilen durdurma kararına uyulmayarak durdurulan işe devam edilmediği yönünde görüş bildirmişlerdir.

6331 sayılı İş Sağlığı ve Güvenliği Kanunu ile getirilen uygulamaların temel amaçlarından biri de, çalışma alanlarında meslek hastalığına neden olan unsurların ortadan kaldırılması ve meslek hastalığının en az düzeye indirilmesidir. İstatistiki veriler incelendiğinde meydana gelen iş kazaları sayısının meslek hastalıkları sayısından çok fazla olduğu görülmektedir. Bu durumun gerçeği yansıtmadığı, meslek hastalıklarının tespitinde yaşanan yetersizliklerin bu tabloyu ortaya çıkardığı söylenebilir [68]. Katılımcıların meslek hastalıklarına neden olan unsurlara yönelik algı düzeylerini belirlemek amacıyla görüşleri sorulmuş ve araştırmaya katılan kişiler çalışma alanlarında en fazla meslek hastalığına neden olabilecek unsurları önem dereceleri sırasıyla tozlar, kimyasal maddeler, fiziksel etkenler ve bulaşıcı hastalıklar şeklinde ifade etmişlerdir. Nitekim, 2013 yılı istakistiki verilerine göre, çalışma hayatında fiziksel ya da ruhsal sağlığı etkileyen elverişsiz faktörlere maruz kalanların toplam istihdam içindeki oranına bakıldığında; toz,duman, kimyasal madde ve gazların etken unsur olarak \%14,1 oranı ile üst sıralarda yer aldığı görülmektedir [69]. Çok riskli bir işkolunda çalışan katılımcıların meslek hastalıklarına neden olan unsurlar ile ilgili algılarının istatistiki veriler ile örtüşstüğü görülmektedir.

KARDEMİR A.Ş'de çalışan alt kademedeki çalışanlar üzerinde gerçekleştirilen bu çalışmada, 6331 sayılı iş sağlığ ve güvenliği kanunu kapsamındaki iş sağlığı ve güvenliği uygulamalarına yönelik algının olumlu olduğu ve katılımcıların demografik özelliklerine göre anlamlı bir farklılık göstermediği saptanmıştır. Katılımcıların güvenlik kültürü yüksek ve kurumsal yönetimin egemen olduğu bir işletmede çalışıłkları dikkate alındığında, katılımcılardaki iş sağlığı ve güvenliği uygulamalarına yönelik bu olumlu algı olağan karşılanmalıdır. Nitekim yapılan bir araşıırmada, güvenlik kültürü yüksek işletmelerde, güvenlik kültürü değişkenlerinden güvenlik farkındalığı, çalışanların katılımı ve raporlama kültürünün çalışanların güvenli davranışları üzerinde pozitif yönlü anlamlı bir etkide bulunduğu gözlenmiştir [70]. Bu anlamda, işletmeye hâkim olan örgütsel kültür ile güvenlik kültürünün tüm çalışanları kuşatıcı etkisinin çalışanlarda benzer algıya neden olduğu ve çalışanların demografik özelliklerini dışladığı söylenebilir. Bu nedenle, katılımcıların 6331 sayılı iş sağlığı ve güvenliği kanunu ile getirilen iş sağlığı ve güvenliği uygulamalarına yönelik algıların olumlu olması ve katılımciların demografik özelliklerine göre anlamlı bir farklılık göstermemesi beklenen bir sonuçtur. Yapılan çalışma ile katılımcıların, işs sağlığı ve güvenliği uygulamalarına yönelik algılarının katılımcıların demografik özelliklerine göre anlamlı bir farklılık göstermeyeceği yönündeki araştırma sorusu doğrulanmıştır. Bu çalışmanın amacına paralel olmak üzere Türkiye genelinde yapılacak olan çalışmaların ilgili literatüre zenginlik kazandıracağı düşünülmektedir.

\section{KAYNAKLAR}

[1] Nayir, A. (2013) "İş Sağlığı ve Güvenliği Eğitiminde Elektrikle Çalışmalara Genel Bakış," Electronic Journal of Vocational Colleges, 3 (3), 129-135.

[2] Albayrak, S. ve Albayrak, A. (2014) "Bir Kamu Kurumundaki İşçilerin İş Sağlığı ve Güvenliği Uygulamalarına Yönelik Algı ve Beklentileri," ÇSGB Çalışma Dünyası Dergisi, 2 (1), 18-28.

[3] Yıldırım, A. Y. ve Kuruoğlu, M. (2013) “Türkiye'de 
ki İşçi Sağlığı ve İş Güvenliğinin ABD İle Kıyaslanması," Beykent Üniversitesi Fen ve Mühendislik Bilimleri Dergisi, 6 (2), 105-120.

[4] Kahraman, Ö. ve Demirer, A. (2010) "OHSAS 18001 Kapsaminda FMEA Uygulaması," Makine Teknolojileri Elektronik Dergisi, 7 (1), 53-68.

[5] Akman, A. ve Koç, U. (2013) "Makinelerin Hareketli Noktalarına Temas Riskinin Değerlendirilmesi," ÇSGB Çalışma Dünyası Dergisi, 1 (1), 120-136.

[6] Kanat, Ş. ve Utlu, Z. (2014) "Gıda Sektöründe İş Kazaları ve Meslek Hastalıkları," Mimar ve Mühendis Dergisi, (80), 88-91.

[7] Kaba, C. ve Ünal, E. (2014) "İstanbul Meslek Hastalıkları Hastanesinde 2009 Yilında Meslek Hastalıkları Nedeniyle Tedavi Edilen Hastaların Hastalık Gruplar1 ve Tedavi Maliyetlerine Göre İncelenmesi,” Türk Tabipleri Birliği Mesleki Sağlık ve Güvenlik Dergisi, (51-52), 43-50.

[8] Akalp, G. (2013) "İşletmelerde Güvenlik Kültürünün Oluşumunda Yönetimin Rolü ve Önemi,” Sosyal Güvenlik Dergisi, 3 (2), 96-109.

[9] Demirbilek, T. (2013) İş Güvenliği Kültürü, İstanbul: Legal Yayıncllı.

[10] Kılkış, İ. (2014) İş Sağlı̆̆ı ve Güvenliği, İstanbul: Dora Yayıncilik.

[11] Callahan, D. (1973) "The Who Definition of Health," The Hastings Center Studies, 1(3), 77-88.

[12] İRİS Akademi İş Sağlığı ve Güvenliği (2014), İş Güvenliği Uzmanlığı Konu Anlatımı, Ankara.

[13] Kılıç, L. (2011) "İş Sağlığı ve Güvenliği Kavramı ve 4857 Sayılı Kanunu Madde 77 Kapsamında İşverenin Yükümlülügüu," Sicil İş Hukuku Dergisi, (22), 91100.

[14] Metinyurt, M. A. (2014) "İş̧̧i Ölümlerinin Sebebi $\mathrm{Ne}$ ?," Mimar ve Mühendis Dergisi, (80), 72-75.

[15] Saraçoğlu, G. V. (2013) “Mesleki Sağlık ve Güvenlik Uygulamalarında Epilepsili Bireyler İçin Sağlığı Geliştirme ve Sağlık Eğitimi,” Türk Tabipleri Birliği Mesleki Sağlık ve Güvenlik Dergisi, (47), 39-45.

[16] Oğuz, Ö. (2011) AB Direktifleri ve Türk İş Hukukunda İş Sağlığı ve Güvenliğinde İşverenin Yükümlülükleri ve İşçilerin Hakları, 1. Baskı, İstanbul: Legal Yayınları.

[17] Gürcanlı, G. E. (2014-5) “İşçi Sağlı̆̆ı ve İş Güvenliği Mücadelesinde Kavramları Netleştirmek, Kavramlarda Ortaklaşmak!,” Türk Tabipleri Birliği Mesleki Sağlık ve Güvenlik Dergisi, (54-55), 77-87.

[18] Alli, B. O. (2001) İş Sağlığı ve Güvenliği Temel
Prensipleri, Cenova: ILO Yayınları.

[19] Baloğlu, C. (2013) "İşverenlerin İş Sağllğı ve Güvenliği Yükümlülükleri ve Aykırılık Hallerinde Uygulanacak Yaptırımlar,” Kamu-İs, 13 (2), 99-125.

[20] Sarıkaya, M., Güllü, A. ve Seyman, M. N. (2009) "Meslek Yüksek Okullarında İş Sağlığı ve Güvenliği Eğitimi Verilmesinin Önemi," TÜBAV Bilim Dergisi, 2 (3), 327-332.

[21] Öztürk, Y. E., Kıraç, R. (2014) "İşverenin ve Çalışanın İş Sağlığı ve Güvenliği Konusundaki Sorumluluğunun Hemşireler Açısından Değerlendirilmesi,” Kahramanmaraş Sütçü İmam Üniversitesi İktisadi ve İdari Bilimler Fakültesi Dergisi, 4 (2), 123-136.

[22] Arıcı, K. (1999) İşçi Sağlığı ve İş Güvenliği Dersleri, Ankara: TES-İş Eğitim Yayınları.

[23] Demircioğlu, M. ve Centel, T. (2005) İş Hukuku, 10. Basım, İstanbul: Beta Yayınları.

[24] Balkır, G. (2012b) "İş Sağlığı ve Güvenliği Hakkının Korunması: İşverenin İş Sağlığı ve Güvenliği Organizasyonu," Sosyal Güvenlik Dergisi, 2 (1), 56-91.

[25] Atayeter, S. ve Atar, H. H. (2013) "TS 18001 İş Sağlığı ve Güvenliği Yönetim Sistemi ve Yüzer Kafes Balık Üretim Tesislerinde İş Sağlığı ve Güvenliği," Yunus Araştırma Bülteni, (1), 27-36.

[26] Ercan, A. (2010) "Türkiye'de Yapı Sektöründe İşçi Sağlığı ve Güvenliğinin Değerlendirilmesi," Politeknik Dergisi, 13 (1), 49-53.

[27] Aksoy, S. ve Çevik, B. ve Çakıcıer, N. (2013) "Gümüşova Meslek Yüksekokulu'nda İş Güvenliği Bilincinin Belirlenmesi," Düzce Üniversitesi Bilim ve Teknoloji Dergisi, (1), 69-76.

[28] Gerek, N. (2006) İşçi Sağlığı ve İş Güvenliği, Eskişehir: Anadolu Üniversitesi

[29] Seyyar, A. ve Kurutkan, M. N. (2004) "Ulusal ve Uluslararası Mevzuat Açısından İş Sağlığı ve İş Güvenliği Sisteminde İşyeri Hekimliği ve İşyeri Hemşireliği Uygulamaları", I. Ulusal Sağlı̆̆ Geliştirme ve Sağlık Eğitimi Sempozyumu Bildiriler Kitabı, Ankara: Poster Bildiri.

[30] Öztürk, H., Babacan, E. ve Anahar, Ö. E. (2012) "Hastanede Çalışan Sağlık Personelinin İş Güvenliği," Gümüşhane Üniversitesi Sağlık Bilimleri Dergisi, 1 (4), 252-268.

[31] Bodur, S., Filiz, E., Durduran, Y. ve Durduran, S. S. (2011) "Mühendis ve Tekniker Adayları İş Sağlığı ve Güvenliğinden Ne Kadar Haberdar?," Harita Teknolojileri Elektronik Dergisi, 3 (3), 9-15.

[32] Mert, B. ve Ercan, P. (2014) "Su Ürünleri Sektörün- 
de İş Sağlığı ve Güvenliği Uygulamalarının Değerlendirilmesi," TÜBAV Bilim Dergisi, 7 (4), 16-27.

[33] Bayılmış, O. ve Taş, Y. (2015) "Sağlık Çalışanlarının İş Sağlğ̆ı ve Güvenliğine Yönelik Yaklaşımlarının Değerlendirilmesi: Sakarya Örneği,” İş, Güç Endüstri İlişkileri ve İnsan Kaynakları Dergisi, 17 (1), 89-117.

[34] Çebi, A. (2014) "İnsanın Onuru, Emeğin Değeri; İş Hayatı ve Güvenliği," Mimar ve Mühendis Dergisi, (80), 54-56.

[35] Akkaya, G (2007) Avrupa Birliği ve Türk Mevzuatı Açısından Sağlık Kuruluşlarında İş Sağlığı, İş Güvenliği, Meslek Hastalıkları ve Bir Araştırma, İstanbul: İstanbul Üniversitesi Sosyal Bilimler Enstitüsü, Yayınlanmamış Doktora Tezi.

[36] Erenoglu, M. (1979) "Kazalar ve Alınacak Önlemler," Acta Orthopaedica et Traumatologica Turcica, 13 (1), 55-59.

[37] Türen, U. ve Gökmen, Y. (2014) “Türkiye'de Meydana Gelen İş Kazaları Sonucu Ölümler ile Çalışanların Yaş Faktörü Arasındaki İlişki," Sosyal Güvenlik Dergisi (SGD), 4 (1), 101-119.

[38] Koç, M. ve Akbıyık, N. (2011) “Türkiye'de İş Kazalarının Maliyetleri ve Çözüm Önerileri," Akademik Yaklaşımlar Dergisi, 2 (2), 129-175.

[39] Çopur, Z., Varlı, B., Avşar, M. ve Şenbaş, M. (2006) "Ege Üniversitesi Hastanesinde Çalış̧an Ev İdaresi Personelinin İş Kazası Geçirme Durumlarının İncelenmesi," Hacettepe Sağlık İdaresi Dergisi, 9 (2), 155 $-176$.

[40] Müngen, M. U. (2011) "İnşaat İşverenlerinin ve Teknik Elemanların İş Güvenliği Konusundaki Sorumlulukları ve Yaptırımlar," Türkiye Mühendislik Haberleri (TMH) Dergisi, (469), 15-24.

[41] Arrkoğlu, Z. (1992) "İşçi Sağlığı ve İş Güvenliği Tanısı ve Amacı," İşşi Sağlığı ve İş Güvenliği Sempozyumu, Ankara: Çalışma ve Sosyal Güvenlik Bakanlığı Yayını.

[42] Tufan, B. (1994) Göçmen İşçilerde İş Kazaları, Ankara: SSK Yayın No: 556.

[43] Tuncay, A. C. ve Ekmekçi, Ö. (2011) Sosyal Güvenlik Hukuku Dersleri, 14. Basım, İstanbul: Beta Yayınları.

[44] Dizdar, E. N. (2001) "Kaza Sebeplendirme Yaklaşımları," Türk Tabipleri Birliği Mesleki Sağlık ve Güvenlik Dergisi, (27), 26-31.

[45] ILO, (1983) Encyclopaedia of Occupational Safety and Health, Geneva: ILO.

[46] Yılmaz, A. (2014) "İş Kazaları ve Kültür: İş Kazaları- nın Önlenmesinde Kültürel Yaklaşım,” International Periodical For The Languages, Literature and History of Turkish or Turkic, 9 (5), 2105-2124.

[47] İlhan, M. N., Kurtcebe, Z. Ö., Durukan, E. ve Koşar, L. (2006) "Temizlik İş̧ilerinin Sosyodemografik Özellikleri ve Çalışma Koşulları ile İş̧ Kazası ve Meslek Hastalığı Sıklığı," F.Ü. Sağlık Bilimleri Dergisi, 20 (6), 433-439.

[48] Dikmen, A. U., Medeni, V., Uslu, İ. ve Aycan, S. (2014) "Ankara'da Bir Üniversite Hastanesinde Çalışan Sağlık Personelinin Geçirdiğini İfade Ettiği İş Kazalarının Değerlendirilmesi," Türk Tabipleri Birliği Mesleki Sağlık ve Güvenlik Dergisi, (53), 22-29.

[49] Güleşçi, Y. (2014) "İşverenin İş Kazası ve Meslek Hastalıklarını Kayıt ve Bildirim Yükümlülüğü (5510 Sayılı SSGSSK ve 6331 Sayılı ISGK Karşılaştırmalı Olarak İnceleme)," Sicil İş Hukuku Dergisi, (32), 152-171.

[50] Topak, O. (2014) "Meslek Hastalıkları Ekonomi Politiği Üzerine Notlar," Türk Tabipleri Birliği Mesleki Sağlık ve Güvenlik Dergisi, (51-52), 2-10.

[51] Zencir, M. (2014) "Mesleksel Bulaşıcı Hastalıklar: Sağlık Çalışanlarının Sağlığı Örneği," Türk Tabipleri Birliği Mesleki Sağlık ve Güvenlik Dergisi, (51-52), 60-69.

[52] Emiroğlu, C. (2012) "Sağlık Sektöründe Mesleki Riskler ve Hukuksal Düzenlemeler," Türk Tabipleri Birliği Mesleki Sağlık Ve Güvenlik Dergisi, OcakŞubat-Mart, 16-25.

[53] Çetin, C, Arslan, M.L. ve Dinç, E. (2014) İnsan Kaynakları Yönetimi, İstanbul: Beta Basım Yayın

[54] Torun, M. (2014) "Maden Faciaları Kader mi? Bu İşin Fıtratı mı?," Türk Tabipleri Birliği Mesleki Sağlık ve Güvenlik Dergisi, (53), 10-13.

[55] Cengizler, F. (2014) "6331 Sayılı İş Sağlığı Ve Güvenliği Yasası'nın Ülkemize Getirisi ve Götürüsü,” İÜHFM, 122 (822), 81-86.

[56] Armstrong, M. (2006) "A Handbook of Human Resource Management and Practice", 10. Baskı, UK: Kogan Page

[57] İnceoğlu, M. (2010) Tutum Alg1 İletişim, İstanbul: Beykent Üniversitesi Yayınları, No: 69.

[58] Aydın, U. (2012) "İş Sağlığı ve Güvenliği Kanunu Tasarısı Üzerine," Sicil İş Hukuku Dergisi, (26), 1018.

[59] Bayram, F. (2010) "İş Sağlığı ve Güvenliği Kanunu Tasarısı Taslağı'nın Değerlendirilmesi," Sicil İş Hukuku Dergisi, (19), 48-62. 
[60] Akın, L. (2010) "İş Sağlığı ve Güvenliğinde Danışmanlık Hizmetinin Hukuksal Sonuçları," Sicil İş Hukuku Dergisi, (18), 33-39.

[61] Özdamar, K. (2001) Spss İle Biyoistatistik, 4. Basım, Eskişehir: Kaan Kitabevi.

[62] Sekaran, U. (2003) Research Methods for Business, Fourth Edition, John Wiley \& Sons Inc.

[63] Krejcie, R. V. ve Morgan, D.W. (1970). Determining Sample Size for Research Activities, Educational and Psychological Measurement, 30, 607-610.

[64] Odabaşı, Y. (1999) “Anket Yöntemi," Sosyal Bilimlerde Araştırma Yöntemleri, Ed.; A. A. Bir, 79-97, Eskişehir: Anadolu Üniversitesi Yayını No: 1081.

[65] Karasar, N. (1995). Bilimsel Araştırma Yöntemi, Kavramlar, İlkeler. Ankara: 3A Araştırma Eğitim Danışmanlık Ltd.

[66] Kalaycı, Ş. (2010). SPSS Uygulamalı Çok Değişkenli İstatistik Teknikleri, 5. Baskı, Ankara: Asil Yayın Dağıtım.

[67] Karacan, E. ve Erdoğan, Ö. N. (2011) “İşçi Sağlı̆̆ı ve İş Güvenliğine İnsan Kaynakları Yönetimi Fonksiyonları Açısından Çözümsel Bir Yaklaşım,” Kocaeli Üniversitesi Sosyal Bilimler Enstitüsü Dergisi, 1 (21), 102-116.

[68] ÇASGEM, (2013) Meslek Hastalıkları, Ankara: Özyurt Matbaacilık

[69] http://www.tuik.gov.tr/jsp/duyuru/upload/ yayinrapor/2013_ISKAZALARI_VE_SAGLIK_PROBLEM LERI_RAPORU.pdf, E.T.: 29.04.2017.

[70] Dursun, S. (2013) “ İş Güvenliği Kültürünün Çalışanların Güvenli Davranışları Üzerine Etkisi” Sosyal Güvenlik Dergisi, 3 (2), 61-75 